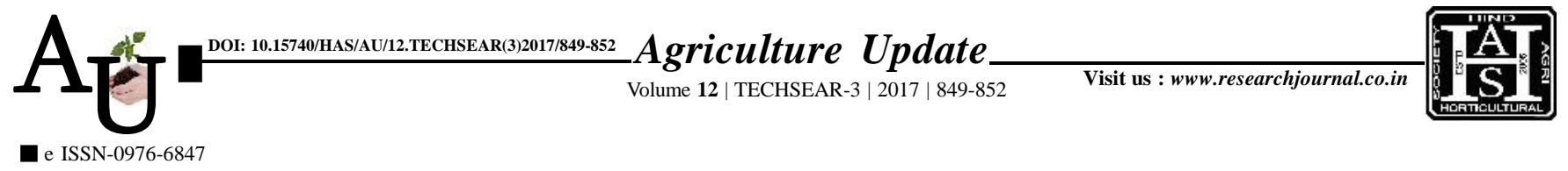

\title{
Research автіcle: Studies on efficacy of AWDI method with field water tube on rice production under SRI
}

\section{S. SANTHEEPAN AND S.P. RAMANATHAN}

Article Chronicle:

Received :

13.07.2017;

Accepted :

28.07.2017

KEY WoRDS :

AWDI, Field water

Tube, Water use

efficiency, SRI, Yield
SUMMARY : The Field experiments were laid out in the wetlands of Agricultural College and Research Institute, Coimbatore during Rabi season of 2013-14 and 2014-15, to study the efficacy of Alternate Wetting and Drying Irrigation method on growth, yield parameters and grain yield of SRI rice with help of field water tube. Nine AWDI treatments were tested along with SRI and conventional rice irrigation methods in Randomized Block Design, replicated thrice. The AWDI levels tested were irrigation at different depletions viz., 10, 15 and $20 \mathrm{~cm}$ below soil surface with their combinations. In both seasons, AWDI after $10 \mathrm{~cm}$ depletion from 7 days after transplanting upto 10 days prior to harvest was found to be superior than other AWDI practices which recorded the highest water use efficiency of 6.82 and 6.27 $\mathrm{kg} / \mathrm{ha}-\mathrm{mm}$ and grain yield of 6352 and $6441 \mathrm{~kg} / \mathrm{ha}$ during Rabi 2013-14 and 2014-15 seasons, respectively. SRI method gave comparable yields with AWDI at $10 \mathrm{~cm}$ depletion, but the water use efficiency was higher under AWDI at $10 \mathrm{~cm}$ depletion.

How to cite this article : Santheepan, S. and Ramanathan, S.P. (2017). Studies on efficacy of AWDI method with field water tube on rice production under SRI. Agric. Update, 12(TECHSEAR-3) : 849-852; DOI: 10.15740/ HAS/AU/12.TECHSEAR(3)2017/849-852.

\section{Author for correspondence :}

\section{S. SANTHEEPAN}

Department of Agronomy, Tamil Nadu Agricultural University, COIMBATORE (T.N.) INDIA

See end of the article for authors' affiliations 